\title{
Atahualpa és Huáscar. Andokbeli országok, Bolívia, Ecuador és Peru néhány történelemkönyvének összehasonlítása (Letenyei László)
}

Eredetileg megjelent:

Századvég, új folyam 21. szám, 2001/2. www.szazadveg.hu

Que viva el Perú, señores!

Desde que era niña aprendi a querer

A esta tierra hermosa que me vio nacer

$Y$ aprendí la historia de mi gran nación

Que llena de gloria nuestro corazón

$Y$ aprendi

Que el Perú es Machu Picchu

$Y$ es el Señor de Sipan

Como las líneas de Nazca

$Y$ las ruinas de Chan Chan

Paracas, Chavín de Huantar,

Los mochicas y los chimúes,

Los huaris, vicús y huancas

Orgullos de mi Perú.

País de hombres y mujeres,

De irreductible valor,

Del Imperio de los Incas

$Y$ el Grito Libertador,

De Junin y de Ayacucho,

Dos de mayo en el Callao,

Perú es Alfonso Ugarte,

Boloñesi y Miguel Grau
Uraim, éljen Peru!

Kislánykoromtól ezt a csodás földet,

Szülóföldemet tanultam szeretni,

És megtanultam nemzetem történelmét

Hogy büszkeséggel teljék meg a szívem

Megtanultam,

Hogy Peru: Machu Picchu,

És a Sipáni úr,

A Nazcai vonalak

És Chan-Chan romjai

Paracas, Chavin de Huantar,

Mocsikák és csimúk

Warik, vikúszok és wankák,

Az én Perum büszkeségei

Az elvitathatatlan értékú

Férfiak és nók földje

Az Inkák Birodalmáé,

És a szabadság kikiáltásáé

Juninban és Ayacuchoban,

Callaoban május másodikán,

Peru: Alfonso Ugarte,

Boloñesi és Miguel Grau 
Que viva el Perú, señores,

Que viva la vida entera!

Que vivan nuestras colores, Arriba nuestra bandera!
Éljen Peru, uraim,

Éljen, míg az élet!

Éljenek nemzeti szineink,

Éljen zászlónk!

ÉnEK: EVA AYllón

Szöveg: Mario Cavagnaro És Oscar Cavero

A történelem-tankönyveket, mint minden iskolai kézikönyvet, kultúraformáló és kultúrateremtô termékként kell felfognunk.

Francisco Bernete

\section{Bevezetés}

Arra az álmúveltségi kérdésre, hogy ki volt az utolsó Inka, a legtöbb magyar olvasó azt válaszolná, hogy természetesen: Atahualpa. Hasonlóképpen a legtöbb perui is ismeri a választ: természetesen Huáscar!

És Atahualpa, kérdezhetnénk, akit Pizarro megfojtatott, miután telehordatott vele egy nagy termet arannyal? Nos, Atahualpa a peruiak szerint egy trónbitorló, Huayna Capac törvénytelen gyermeke, aki megölette Huáscart, a legitim uralkodót, miután ô maga Pizarro fogságába esett. Ezért ítélték halálra a perui történetírásban nemes lelkúnek nevezett konkvisztádorok, és helyette királyi vérbôl származó unokatestvérét, a fiatal Mancót segítették a trónra. Pizarro elismert hôs Peruban, akinek lovas szobra áll a San Marcos téren, földi maradványait pedig egy kis kápolna ôrzi a limai katedrálisban.

Az ecuadoriak szerint azonban épp ellenkezôleg: Atahualpa volt Huayna Capac kedvenc gyermeke, és fele királyságának örököse, aki jogosan védelmezte örökségét a Peruból támadó Huáscarral szemben. Huáscar egyébként is gyenge jellemú volt, megérdemelte sorsát, szemben Atahualpával, akit az egyébként analfabéta és foglalkozására nézve disznópásztor Pizarro orvul gyilkoltatott meg. 
Atahualpa és Huáscar küzdelmei napjainkban éppen úgy megosztják a térség lakóit, mint annak idején a XVI. században. A középeurópai olvasó számára nem az túnik furcsának, hogy szomszédos országok történetírásai eltérô módon interpretálnak egy történelmi eseményt, hanem inkább az, hogy olyan országokról van szó, amelyek között egy kívülrôl érkezố megfigyelố nem tud különbségeket felfedezni. Míg a mi térségünkben a legtöbb ország külön nyelvvel, eltérố népi kultúrával és hosszabb idôre visszanyúló önálló történeti fejlôdéssel rendelkezik, az Andok szóban forgó három országáról mindezek nem mondhatók el. Ecuadorban, Peruban és Bolíviában közös a hivatalos nyelv, a spanyol, ráadásul mindhárom országban ugyanaz a népcsoport, a kecsua, illetve az ajmara teszi ki legnagyobb etnikai kisebbséget. Hasonló a három ország gazdaságszerkezete, és hasonló a „társadalmi piramis”, amelynek csúcsán a kreol gazdasági elit, alján az ôshonos földmúvesek találhatók, a középosztály pedig az egyre bôvülố mesztic népesség. Regionális különbségek persze vannak, és ezek nemegyszer etnikai-kulturális és földrajziéghajlati különbségeket is takarnak, az országhatárok azonban nem a regionális határok mentén húzódnak, épp ellenkezóleg, többnyire szervesen egybetartozó térségeket szakítanak szét. A perui -bolíviai határ például az Altiplano-fennsík közepén, a Titicaca-tavon keresztül húzódik, az ecuadori-perui határ pedig a suár népcsoport földjét vágja ketté. Összefoglalva gondolatmenetünket: egy kívülálló szemével nézve nem érthetố, hogy miért osztják meg államhatárok az Andok országait.

A térség történelme a XIV. századtól a XVIII. századig közös történelem volt. A mai Ecuadortól Chile közepéig terjedố hegyvidéket elốbb az Inka-uralom, majd a XVI. század közepétốl megerôsödô spanyol alkirályság egyesítette. A XIX. században függetlenedô köztársaságok azonban a XX. századra már nemcsak földrajzi, de történelmi értelemben is kisajátították az ország területét, és megszülettek a nemzeti történelmek. Napjainkban az egyes országok történetírása - pontosabban történelemoktatása - olyan történel- 
met sugall az új nemzedékek számára, amelyben csak az egyes országterületekre esố történelmi események kaptak helyet. A folyamat megfelel Anthony Douglas Smith elképzelésének, miszerint egy nemzet és a nemzeti sajátságok (mint a nemzeti történelem) ott jöhetnek létre, ahol van olyan politikai csoport, amely érdekeit a nemzetté válásban véli felfedezni (Smith 1994).

A három távoli ország jó példa arra, hogy hogyan lehet nemzeti történelmet csinálni egy alapvetôen nemzetek feletti történelmi idôszak eseményeiból. A tanulmány a történeti antropológiai iskola nemzetfelfogását követi elsôsorban Weber (1975), Hobsbawm (1983), Anderson (1983) és Hofer-Niedermüller (1988) nyomán. Szemléletünkben a nemzeti történelem egy állam vagy más politikai csoport által különbözô eszközök révén kialakított közös tudás, amelynek egyes elemei azonban korábban is ismerhetôk voltak a nemzetnek tekintett népesség egy részénél vagy egészénél.

Az alábbiakban a nemzeti történelem konstruálásának folyamatát igyekszem tetten érni az iskolai történelemoktatás összehasonlításával. Arra keresem a választ, hogyan áll össze az a tananyag, amelyet az iskolás gyerekek nemzeti történelem gyanánt sajátítanak el az Andok országaiban, hogy, Eva Ayllónnal szólva „büszkeséggel teljék meg a szívük".

\section{1. ábra. A nemzeti történelem konstruálásának folyamata}

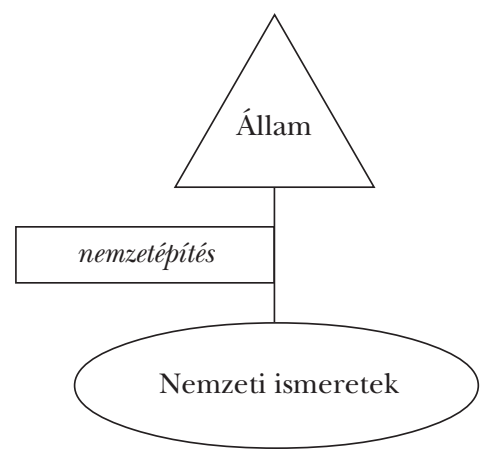


A tanulmány egyszerú módszertant követ: a három országban kiadott hivatalos történelem-tanterveket állítottam (kissé módosítva) egymás mellé egy táblázatba, és így hasonlítottam össze az egyes országok számára legfontosabb eseményeket, illetve történelmi személyiségeket. A táblázatokat a következô oldalakon mutatom be. A tantervek Ecuadorban és Peruban minden állami iskolában megtalálhatóak. A táblázatok csak neveket, események megnevezéseit és dátumokat tartalmaznak, kronologikus sorrendben, feltételezve, hogy az iskolák és a tankönyvek majd elvégzik az adatok értelmezésének feladatát. Bolíviai tanterv nem állt rendelkezésemre, ezt tankönyvek és interjúk alapján rekonstruáltam. A tankönyveket és a tanárokkal készített interjúkat az ecuadori és a perui tantervek helyes értelmezéséhez is felhasználtam. 


\title{
Az Andok történelme három nemzeti interpretációban
}

\author{
1. táblázat
}

Az Andok történelme három nemzeti interpretációban

ECUADOR

PERU
BOLÍVIA

A KEZDETEKTố L A X V. SZÁZA D I G

PREHISTORIA

Az ember Amerikában:

40 vagy 24 ezer éve

Az elsố andokbeli

kultúra

Kr. e. 3400: Valdívia

Autochton kultúrák

La tolita, bahía,

coaque stb.

Az integráció kora

Manteña, milagro, cara,

cañari stb. kultúrák

0: Kito indián alapítása

1450 körül:

„Kitói Konföderáció”

és térképe

1488: a yaguarcochai csata és az inka hódítás Huayna Capac átteszi az udvarát Kitóba 1528: Atahualpa, Huayna Capac fia lesz Kito királya

\section{N K A - K O R}

Elméletek az Andok

benépesülésérôl

Az elsố andokbeli

kultúra

Kr. e. 2800: Chavín

Kultúrák

Nazca, paracas, moche, recuay, ica, chincha stb.

Birodalmak

Huari Birodalom

Chimú Birodalom

XIII. sz.: Cusco

alapítása

1325: chancas támadás

Birodalmi kor: 12 inka,

3 nagy inka

„Perú Antiguo” térképe

Huayna Capac halála

1528-1532:

polgárháború

Inka szociális

társadalom

Kulturális eredmények
Ember 40000 éve

Amerikában

21000 éve Bolíviában

Az elsố andokbeli

kultúra

Kr. e. 600 Kr. u. 800

Tiawanaco és a

Tiawanaco-Warí

Birodalom

Ajmara királyságok

Más kultúrák: uru, puq'ina

A Kolla-királyság térképe

XIV-XV. sz.: Inka invázió

A Kolla-királyság Pachacutec, az inka Az Inka Birodalom és benne Kollasuyo térképe Az autonóm Kollasuyu történelme 


\section{G Y A R M A T I K O R}

HISTORIA

1492, 1513, 1526:

Amerika, Mexikó és

Ecuador felfedezése

1532: Pizarro

partraszállása

Tumbesben

1532: Atahualpa

meggyilkolása

1534: Quito spanyol alapítása

1534: Benalcázar, a hôs legyôzi és kivégzi

Rumiñahuit, a másik hôst

1535: Guayaquil megalapítása

1542: az Amazonas felfedezése

1544: kreol felkelés

a perui alkirályság ellen

1563: a Real Audiencia de Quito létrehozása 1586: A jezsuiták megérkezése; az elsô andokbeli Ágoston rendi egyetem megalakítása

1688: A Colegio San Francisco alapítása 1740: A mai Ecuador területét a Bogotai Alkirálysághoz csatolják

Kreol nemzeti mozgalmak A korszak során gyarmati társadalom és gazdaság, quitói múvészeti iskola
Az Inka Birodalom

bevonása a nyugati

kultúrába

1492: Amerika

felfedezése

1532: Pizarro

partraszállása

Peruban vagy

Tumbesben

1532: Pizarro gyôzelme

Cajamarcában

1532-37: Peru távoli

vidékeinek

meghódítása

1535: Lima alapítása

1537: II. Manco

felkelése

1542: az Amazonas

felfedezése

Perui alkirályság

1542: Az alkirályság

megalapítása

1544: A Gonzalo

Pizarrofelkelés

1571-: Toledo alkirály

1572: Vilcabamba

bevétele

Garcilaso de la Vega

1551: Real y Pontificia

Universidad de San

Marcos

1742-56: Juan Santos

Atahualpa vezette

felkelés

1780: II. Tupac Amaru

forradalma

Kreol függetlenségi

mozgalmak

A korszak során

gyarmati irodalom és

múvészet
Gyarmati kor

1492: Amerika

felfedezése

1532-33: Pizarro

Cajamarcában

1534: Diego de

Almagro

megérkezése

1534-37: Collasuyu

meghódítása; Nueva

Toledo kormányzóság,

majd Chilei Audiencia

megalapítása

1537: Diego de

Almagro felmenti

Cuscót Mancótól

1548: La Paz alapítása 
Az 1. táblázat arról árulkodik, hogy az andokbeli három ország területi alapon felosztotta egymás között a térség történelmét. Mindhárom országban olyan eseményeket tárgyalnak, amelyek az adott országban történtek, még akkor is, ha annak az eseménynek a maga idejében csak regionális jelentôsége volt. Elhallgatnak ugyanakkor olyan eseményeket, amelyek a többi ország területén mentek végbe, még ha azok nem is lennének elválaszthatók egymástól.

A történelem felosztásából következik a tankönyvek eltérô szemlélete: más eseményeket tárgyalnak, és éppen ezért más kérdéseket is vetnek fel. A vizsgált idôszakban mindössze hat olyan eseményt találhattunk, amelyek egyforma jelentôséggel szerepeltek mindhárom ország tanterveiben, illetve tankönyveiben. Ezeket nevezem „csomópontoknak”, és a továbbiakban elsôsorban ezek vizsgálatával foglalkozom. A hat csomópont a következô volt: az elsô andokbeli kultúra kérdése; az inka hódítás, illetve uralom; a spanyolok megérkezése; a fốváros alapítása; az elsố egyetem alapítása; a függetlenségi harc.

Az elsố andokbeli kultúra kérdése feltehetôen azért megkülönböztetett jelentôségú mindhárom ország számára, mert az ôsiség, a nemzet régiségének mítoszát hordozza magában. Kívülálló számára nyilvánvaló, hogy legrégebbi andokbeli kultúra csak egy lehet. A kérdésnek egyébként sincs történelmi jelentôsége, mert túl keveset tudunk az Andok benépesülésérôl és az Inka-kor elôtti migrációs folyamatokról ahhoz, hogy akármelyik leletegyüttest az andokbeli kultúrák bölcsôjének kiálthatnánk ki. A tankönyvek legfeljebb legrégebbi feltárt ecuadori, perui stb. kulturális emlékekrôl, pontosabban a mai országok területén fellelhetố legrégebbi leletekról beszélhetnének.

Ha történeti jelentôsége nincs is az elsố kultúra kérdésének, gyakorlati jelentôsége van, mert a nemzetépítés egyik kulcskérdésévé nôtte ki magát. Ennek megfelelôen a három ország három különbözố régészeti lelôhelyet ismer el legrégebbi andokbéli kultúraként. 
Franz Tamayo, a neves bolíviai történész például így ír Tiahuanaco romjairól: „Az Altiplano volt a legrégebbi preinka civilizáció, Tiahuanaco bölcsôje, amelynek eredetisége és a többi hatalmi központokkal szembeni ellenállóképessége tette lehetôvé az egész térség függetlenségét." (Tamayo 1910, 118)

Tamayo nézeteit osztják a bolíviai tankönyvek is, lokális kultúráknak, nem pedig „civilizációnak” minôsítve az egyébként vitathatatlanul régebbi perui régészeti központokat, és az ecuadori tengerparti kerámialeleteket.

ECUADOR

PERU

BOLÍVIA

A Z E L S Ô A N D O KBELI KULTÚRA

Kr. e. 3400: Valdívia

Kr. e. 2800: Chavín

Kr. e. $600 \mathrm{Kr}$. u. 800 :

Tiawanaku

A preinka kultúrák tárgyalásánál (ezt a kifejezést egyébként ma már csak a perui történetírás használja), sajnos, egyik tanterv sem nyújt pán-andokbeli panorámát. A történeti kutatások szerint az egyes kulturális központok hatása távoli tájakra kisugározhatott, az oktatás során azonban nem ennek a folyamatnak a bemutatása a cél, hanem csak az adott országterületre esố régészeti lelóhelyek bemutatására törekednek.

ECUADOR

PERU

BOLÍVIA

A N D O K B E L I K U L T ÚRÁK A Z I NKA-KOR E L ỐT T

Autochton kultúrák

Kr. e. 500 Kr. u. 1200

La Tolita, Bahía,

Coaque, stb.

Az integráció kora

Kr. u. 1200-1500

Kitói Konfederáció,

Shyri királyság
Preinka kor

Nazca, paracas, moche, recuay, ica, chincha stb.

kultúrák

Birodalmak

Warí, Chimu

Királyságok kora
Tiawanaco-Warí

Birodalom

Ajmara királyságok

Kolla-királyság 
Érdekes megfigyelni, hogy a korszak megnevezése is különbözik a három országban. Az inka hagyományokat Valcárcel óta felvállaló Peruban az Inka-uralom elốtti kort preinkának nevezik, míg a helyi szerves fejlôdést hangsúlyozó Ecuadorban autochton kultúrákról, illetve a (helyi) integráció koráról beszélnek. Bolíviában a spanyol hódítás elốtti idôszakot nem osztják korszakokra, az inka hódítás elốtti idôszaknak nincs összefoglaló megnevezése. A történelemkönyvekbốl mégis leszúrhetô, hogy eleinte kultúrákról, majd többnyire királyságokról beszélnek.

Az inka hódítás elốtti idôszak tárgyalásánál bukkannak fel elôször a kortárs területi igények történelmi igazolásai. Ezek megértéséhez röviden be kell mutatnunk az andokbeli országok valós és képzelt országhatárai közötti különbségeket. A képzelt országhatárok mindig jóval kiterjedtebbek, mint a valósak: Ecuador szerint a jelenleg perui Tumbes és az Amazonas folyó is az országhoz tartozik, Bolívia pedig a rég elveszített tengerpartot és a Gran Chacót tekinti bolíviai területnek. Peru többnyire az egész Andok központjaként szokta feltüntetni Limát és az országot.

Ezek a képzelt térképek ugyan nem tükrözik a valós politikai viszonyokat, de az adott országokban tudatformáló hatásúak. Ecuadorban például az iskolában és a hivatalokban kizárólag NagyEcuador térképét lehet látni, és kizárólag a külföldi kiadású térképekbốl lehet megtudni, hogy hol is van most a két ország 1941-ben megállapított határa.

Az ôsi kultúrák tárgyalása a képzelt és nem a valós államhatárok alapján történik, így például Ecuadorban tárgyalják a Tumbesben feltárt leleteket, Bolíviában pedig az Atacama-kultúra maradványait. Az államhatárok 150-180 éves problémája így 3000 éves igazolást nyert.

A nemzet vizuális ábrázolása, azaz a nemzetállam területét bemutató elsố térképek is ebbốl az idốszakból, pontosabban az „integráció”, illetve a „birodalmak” korából származnak. Az Ecuadori kézikönyvek a Kitói Konföderáció térképét mutatják be, amelynek 
kiterjedése megegyezik a politikai „Nagy-Ecuador” területével, magába foglalva Tumbest és az Amazonas-vidéket is. Talán nem szükségtelen elmondani a magyar olvasók számára, hogy egy ilyen térkép felvázolása mennyire történelmietlen, hiszen még a jóval késóbbi Inka Birodalom történelmi határait is bizonytalanul ismerjük. Az azonban bizonyos, hogy a Kitói Konföderáció (amelynek létezésére egyébként nincsenek történelmi dokumentumok) nem terjedhetett ki az ôserdô vidékére, amely még a gyarmati idôszakban is ritkán lakott és gyakorlatilag független terület maradt.

A bolíviai tankönyvek ebból az idôszakból leginkább az ajmarának tartott Kolla-királysággal foglalkoznak. A bolíviai interpretáció szerint ez az Inkák elôtti formáció szervezte volna egységbe a mai NagyBolívia hegyvidékének népeit, és határai egészen a mai Közép-Chiléig nyúltak. A tankönyvek szerint a terület az inka hódítás után is megốrizte autonómiáját, ezért nevezték a területet az Inkák Collasuyunak. Ez utóbbi megállapítás (perui szemmel) nem felel meg a valóságnak, hiszen az Inka Birodalom négy tartománya közül többet valamilyen népcsoportról neveztek el (az északi például a Chinchasuyu nevet viselte a harcias csincsa népról), ezek azonban nem voltak autonómabbak vagy kevésbé autonómak a többinél. Az egyik tankönyv térképmelléklete az Inka Birodalmon belül eltérô színnel ábrázolja Chinchasuyut, amely körülbelül a korábbi Kollakirálysággal, illetve a politikai Nagy-Bolíviával egyezik meg.

A perui történelemkönyvekben az elsố országterületet bemutató térképvázlat az Inka Birodalomé. A birodalom, Tahuantinsuyu legnagyobb kiterjedése idején felölelte a mai Ecuador, Peru és Bolívia, Észak-Argentína és Észak-Chile hegyvidéki területeit. A térképvázlat az ország regionális vezetố szerepre vonatkozó igényeit támasztja alá. Sokatmondó a térkép címe is: Perú antiguo, azaz régi Peru. Külön érdekesség, hogy ugyanakkor az ecuadori tankönyvek egyikében sem kerül bemutatásra az Inka Birodalom térképe.

Az egyenes vonalú helyi fejlôdés bizonyításának igénye, illetve a „birodalmak”, „királyságok” és „integrációk” éles megkülönbözte- 
tése a „kultúráktól”, illetve „autochton kultúráktól” több logikai bukfenchez is vezet a történelem tárgyalása során. A perui tankönyvekben például a Nazca-kultúra a Warí Birodalom eloótt kerül tárgyalásra, holott egy idôben késôbbi jelenségrôl van szó.

A három ország történelemoktatásában talán az Inka Birodalom megítélésében mutatkoznak a legnagyobb különbségek. Az ecuadori tankönyvek hangsúlyozzák, hogy a független Shyri királyokat és a Kitói Konföderációt leigázó Inkák barbár harcosok voltak, akik a katonáskodáson kívül kevés dologhoz értettek. Saját megfigyeléseim szerint ugyanakkor, szemben a hivatalos történelemszemlélettel, a hegyvidéki lakosság 50-60 százalékára becsült kecsua népesség körében erôs a nosztalgia az Inka Birodalom iránt.

A perui kézikönyvek a harmincas évek indigenistáinak szemléletét veszik át, és az Inka állam szociális vívmányait, a létbiztonságot emelik ki. A bolíviai tankönyvek ugyanakkor az egész megszállásnak kis jelentôséget tulajdonítanak, hiszen ott szerintük épen megmaradt Collasuyu autonómiája.

A spanyol gyarmati uralom kezdete mindhárom ország tankönyveiben új fejezetet nyit, amelyben 1492-tôl kezdôdően kezdik tárgyalni a spanyolok térhódítását az Újvilágban. Az ecuadori történelemkönyvek ezt azzal teszik még hangsúlyosabbá, hogy csak a spanyolok megérkezésétól kezdve beszélnek történelemrôl (historia), az indián kultúrák korát pedig, beleértve az Inka-idôszakot is, „történelem elôtti idôszakként” (prehistoria) tárgyalják. Ez a megkülönböztetés egyébként interjúim szerint súlyosan sérti a lakosság többségét kitevô ôshonos népesség identitását.

A másik két országban is külön korszakot jelent a „gyarmati idôszak” (época colonial), de az inka hagyományokat felvállaló Peruban ezt „az Inka Birodalom beágyazódása (incorporación) a nyugati kultúrába” alcímmel látják el. A „gyarmati idôszak” szerintük csak késôbb, 1542-ben az alkirályság megalapításával kezdôdött. 


\section{2. táblázat \\ Az elsố évek legfontosabb eseményei}

ECUADOR

PERU

BOLÍVIA

1492, 1513, 1526: AMERIKA, MEXIKÓ ÉS ECUADOR FELFEDEZÉSE

Történelem

(megkülönböztetésül

az elôzố koroktól, ami

„prehistória”)

1532: Pizarro

partraszállása

Tumbesben

1532: Atahuallpa

meggyilkolása

1563: a Quitói Királyi

Helytartóság

megalapítása

A korszak során: a quitói festészeti iskola
Az Inka Birodalom

bevonása a nyugati

kultúrába

1532: Pizarro

partraszállása

Peruban vagy

Tumbesben

1532: Pizarro gyốzelme

Cajamarcában

1535. január 18.: Lima alapítása

A korszak során: a gyarmati szépmúvészet és irodalom
Gyarmati kor

1532-33: Pizarro

Cajamarcában

1534: Diego de

Almagro

megérkezése

1534-37: Collasuyu

meghódítása

1563: a Chacrasi

Audiencia

megalapítása

A korszak során: a

Chacrasi Audiencia a

Spanyol Birodalom

kincsesbányája

Az egyik legfontosabb kérdésben, Amerika felfedezésének időpontjában és interpretációjában egyetértenek a tankönyvek. Nem azonos a válasz azonban arra a kérdésre, hogy ki és mikor fedezte fel az Andok térségét. A perui és boliviai tankönyvek hozzánk hasonlóan Francisco Pizarrónak tulajdonítják az érdemet, aki 1532-ben kötött ki Tumbesben, az ecuadoriak azonban Bartolomé Ruiz 1526- 
os utazását tartják a valódi felfedezésnek, aki a történelmi dokumentumok szerint valóban eljut(hat) ott Ecuador partjaiig.

Mindhárom ország történelemkönyvei kiemelik a helyi központ, a mai fôváros alapításának, vagy spanyol újraalapításának eseményeit. Quito indián város volt, amely spanyol gyarmati székhely lett, Limát a spanyolok alapították, Chuquisacát, a mai Sucrét, Bolívia kvázifôvárosát pedig az ezüstbányászat hívta életre. A három történetírás közül azonban csak a peruiból derül ki, hogy a XVIII. század közepéig az egész terület a Perui Alkirályság része volt, és így Quito vagy Chuquisaca szerepe nem volt nagyobb, mint például a szintén regionális jelentôségú Trujillóé.

A szomszédos országokban alapított városokat a tankönyvek természetesen nem tüntetik fel, így például az ecuadori tanulók számára nem derül ki, hogy mikor alapították Limát vagy Chuquisacát.

A kortárs politikai viszonyok múltba való visszavetítését mutatja az is, hogy például az ecuadori gyermekeknek az 1530 és 1830 közötti idôszakra vonatkozóan is meg kell tanulniuk „Ecuador kormányzóit”, tehát egy olyan idôszakra vonatkozóan, amikor Ecuador még nem létezett (Pareja 1991, 112).

A gyarmati uralom évszázadai során a tankönyvek elsôsorban egyetemek alapításairól, irodalmi és képzốmúvészeti alkotásokról számolnak be. A történelem földrajzi felosztása természetesen itt is érvényesül: a peruiak nem tudnak a chuquisacai egyetem vagy a quitói festôiskola jelentôségérôl, mint ahogy azok sem a perui kulturális eredményekrôl. Nem derül ki a tankönyvekbôl az egyes iskolák egymásra hatása, sem az a birodalmi univerzalizmus, amelynek keretében egyes spanyol vagy kreol múvészek egy másik alkirályságban, sôt, egy másik kontinensen folytathatták a tevékenységüket. 


\section{Nemzeti panteon}

A legrégebbi nemzeti hôsöket Bolívia tudja felmutatni. Az anonimitásból elôször a Kolla-uralkodók lépnek személyként a nemzeti történelem színpadára. A spanyol krónikákból csak utalásszinten megismert és nem nevesített Kolla-uralkodók valószínúleg éppen azért válhattak Bolívia nemzeti hôseivé, hogy a nemzeti panteonban a perui Inkáknál ôsibb személyek szerepeljenek. Hasonló lehetett a szándék Ecuadorban is, ahol az Inkák ellensúlyozására a tankönyvek a szintén csak utalásszinten ismert Schyri királyokat tartják a térség elsô uralkodóinak. A tankönyvek illusztrációi között még a XIV. Shyri és lánya, a krónikák által egyedül nevesített Toa hercegnố elképzelt arcképei is láthatóak.

\section{3. táblázat}

Nemzeti Panteon a három andokbeli országban

ECUADOR

PERU

BOLÍVIA

NEMZETI HÔSÖK KEZ D E TEKTÓL A XV. S ZÁZAD I G

XIV. Shyri,

a Kitói Konföderáció

alapítója

Toa hercegnô,

Huayna Capac ellenfele

Atahualpa,

a quitói inka királyfi

Rumiñawi,

Atahualpa testvére

és harcostársa,

Quito védôje

1534-ben Benalcázar,

Quito meghódítója

1534-ben
Señor de Sipan

Manco Capac,

Qozqo alapítója

A nagy Inkák:

Pachacutec,

Tupac Yupanquí,

Huayna Capac

Huáscar,

a legitim utolsó Inka
Kollák, azaz a régi

Bolívia uralkodói

(és/vagy lakosai)

Hanan Colla, a független Collasuyo utolsó uralkodója

Pachukuti Inka, Collasuyo meghódítója 


\section{G Y A R M A I K O R}

Cristóbal Colón

Bartolomé Ruiz,

Ecuador felfedezôje

1526-ban

Benalcázar, a spanyol

Quito alapítója

Orellana, az Amazonas

felfedezóje

Gonzalo Pizarro, aki felkelt a limai alkirály ellen
Cristóbal Colón

Francisco Pizarro

Gonzalo Pizarro, az Amazonas

felfedezóje

I. Tupac Amaru

Toledo alkirály

II. Tupac Amaru 1781 „Protomartires”
Cristóbal Colón

Gonzalo Pizarro és Pedro de Alvarado, Collasuyu meghódítói

Alfonso de Mendoza, La Paz alapítója

Tomas és Tupac Katari, 1783.

Medina szerzetes a „La

Paz-i felkelés atyja”

„Protomartires” del

Alto Perú

F Ü G G E T L E N S É G I H Á B O R Ú

Simón Bolívar,

a Libertador,

(megvédte Guayaquil

függetlenségét Perutól

és San Martíntól)

Antonio Sucre,

Quito elsô elnöke

Juan José Flores, a Köztársaság elsố elnöke
San Martín

Simón Bolívar,

a Libertador

Felipe Salaverry,

elnök,

mártír Antonio Sucre, az Ayacuchoi gyôzelem tábornoka
Antonio Sucre, Bolívia elsố elnöke

Simón Bolívar és Antonio Sucre, az ország alapítói

Santa Cruz 
Peruban az Inkák a legkorábbi nemzeti hôsök. A korábbi idôkre datált híres leletegyüttes, a „Sipáni úr” ugyan a perui nemzeti büszkeség egyik tárgya, a díszesen eltemetett múmiát azonban a tankönyvek (helyesen) nem történelmi személyként, hanem régészeti kincsként interpretálják. Elevenen él ugyanakkor a tizenkét Inka uralkodó, és elsôsorban a három „nagy”, Pachacutec, Tupac Yupanquí és Huayna Capac nemzeti tisztelete.

Az Inkák megítélése Ecuadorban sokkal ellentmondásosabb. A történelemkönyvek a Quito elfoglalásáról szóló fejezetben (1488) Huayna Capacot még kegyetlen zsarnokként és hódítóként írják le (a pozitív szereplố Toa hercegnô), de a hadjárat alatt született fia, Atahualpa egy ízig-vérig quitói hadfi lesz, aki a perui Inka, Huáscar ellen küzd. Bolíviában viszont egyik Inka sem számít legitimnek, hiszen mindketten Collasuyu megszállói.

Az egyetlen „nemzeti” hôs, amelynek tiszteletében egyetértenek a történelemkönyvek, Kolombusz Kristóf. Mindhárom országban munkaszüneti nap és nemzeti ünnep a „Faj napja” (Día de la Raza), Amerika felfedezésének évfordulója. Az ünnepen azonban a perui, bolíviai és ecuadori ôshonos népek mozgalmai tüntetôleg nem szoktak részt venni, sốt a kilencvenes években többnyire ellentüntetéseket szerveztek. „Milyen faj napját ünnepelnénk - kérdezte tôlem 1993-ban a FICI óshonos mozgalom egyik vezetôje -, amikor mi már jóval az úgynevezett felfedezés elôtt is itt éltünk...”

A többi történelemformáló spanyol vagy kreol hốs megítélése távolról sem ennyire egybehangzó a három országban. Francisco Pizarro például nemzeti hôs Peruban, bárdolatlan zsarnok Ecuadorban, és jelentéktelen mellékfigura Bolíviában, Diego Almagro fegyvertársa.

A mesztic identitásépítés sajátja, hogy olykor a gyôzoók és a legyốzöttek egyaránt helyet kapnak a nemzeti panteonban. Például, az ecuadori hegyvidék leigázója, Benalcázar és az ellene küzdô tragikus sorsú indián vezér, Ruminahui egyaránt Ecuador nemzeti hôsei.

Az Amazonas felfedezôje, Orellana, illetve a kalandos utazás részletei mind a perui, mind az ecuadori tankönyvekben fontos helyet 
kapnak, jelezve, hogy mindkét ország történelmi igényt formál az ôserdei tengeri kijáratra. (Bolíviai tankönyvekben az expedícióról csak néhány soros említést tesznek.) Egy ecuadori kézikönyv például az alábbi szöveggel kíséri a felfedezést megörökítô képillusztrációt: „Francisco de Orellana és az Ecuadoriak [sic!] felfedezik az Amazonast” (Pareja 1991, 56). Egyes perui tankönyvek viszont a felfedezés dicsôségét nem Orellanának, hanem az expedícióban valóban részt vevô Gonzalo Pizarrónak tulajdonítják, megjegyezve, hogy akkoriban már cuscói lakos (tehát perui) volt.

A gyarmati idôszak utolsó évtizedeinek függetlenségi harcosai közül (bolíviai szóhasználattal a „protomártírok”) egyedül a perui források emelik ki a legnagyobb indián származású forradalmár, José Gabriel Condorcanqui avagy Tupac Amaru személyét és jelentôségét. Bolíviában róla nem, inkább egyik alvezérérôl, Tupac Katariról írnak, Ecuadorban pedig egyikrôl sem, pedig a felkelés az akkor már nem a limai alkirálysághoz tartozó tartomány területére is átterjedt. A többi indián származású szabadságharcosról, például Pumacahua vagy Atahualpa Apu harcairól egyik országban sem tudósítanak részletesen.

A függetlenségi háborúk hôseinek tisztelete ma átnyúlik a nemzeti határokon. Bolívia kulturális fôvárosa és Ecuador nemzeti pénze például egyaránt Sucre tábornok nevét viseli, Bolívarnak pedig egyaránt állnak szobrai Limában, La Pazban és Quitóban. Nemzeti jellegúvé attól váltak a felszabadítási háború eseményei, hogy az egyes tankönyvek mindig csak az adott nemzeti országterületre esố felszabadítási harcokról számolnak be. Bolívia nemzeti ünnepe például a függetlenség kikiáltásának napja (augusztus 6.), amit Bolívar az utolsó királyi csapatok legyôzésének egyéves évfordulójára idôzített. A tankönyvek azonban elhallgatják, hogy a juníni ütközet a mai Peru területén zajlott, ahol kolumbiai és argentin felkelô csapatok ütköztek meg a spanyol katonai alakulatokkal. 


\section{Történelem- és nemzetkonstruálás}

Herder sokat idézett és rossz emlékúvé vált meghatározása, miszerint minden népnek rendelkeznie kell saját nyelvvel és saját kultúrával, elég nehezen alkalmazható az andokbeli nemzetek esetében. Ezeknek a nemzetállamoknak nincs saját nyelve, sem egymástól eltérô történelmikulturális hagyományai. Az országok közötti hasonlóságok nagyobbaknak túnnek, mint a különbségek.

A három vizsgált ország az Inka-uralomtól kezdve a XVIII. század végéig egy társadalmi-politikai formációhoz tartozott.

Hasonló társadalmi átalakulásokon mentek keresztül, a múlt század oligarchikus-demokratikus berendezkedésétôl kezdve az elmúlt évtizedek baloldali útkereséséig.

A társadalom etnikai alapú osztályszervezete mindhárom országra jellemzô, és más országokban ismeretlen jelenség (Letenyei 1998, 87).

Mindhárom országban jelentôs ôshonos (elsôsorban kecsua és ajmara nyelvú) népesség él, amelyek számarányukat tekintve talán az ország többségét teszik ki, politikai és gazdasági érdekérvényesítô képességük azonban gyenge.

A közép-európai nemzetekkel ellentétben a paraszti népesség által beszélt nyelvek nem tudtak felemelkedni a múvelt nemzeti nyelvek közé, az oktatás és a hivatali ügyintézés nyelve kizárólag a spanyol.

A paraszti kultúra elemei nem váltak a „nemzeti” kultúra részévé, szemben a mi térségünkkel, ahol ennek nagy szerepe volt a modern nemzetek kialakulásában.

Mindezek ellenére az andokbeli országok valóban nemzetekként viselkednek: megalkották és tisztelik saját nemzeti jelképeiket, nemzeti keretek között múködik a gazdaság, sốt a nemzeti erôforrásokat a közelmúltban nemegyszer egymás elleni háborúkra is fordították.

A nemzeti történelem kialakítása és oktatása fontos szerepet játszik abban, hogy az egyes országok vezetô gazdaságielit-csoportjai el tudják fogadtatni az egyébként kulturálisan semleges népességgel, 
hogy vannak nemzeti érdekeik. Az oktatásnak köszönhetôen az iskolások elól rejtve maradnak az andokbeli országok hasonló vonásai, egyebek közt az is, hogy közös történelmük évszázadokon át egybekapcsolta óket.

A három ország történelemoktatása nemzeti alapon szervezôdött meg, és a térség történelmi eseményeit földrajzi alapon osztották fel egymás között:

\section{2. ábra}

\section{A történelmi tudatépítés}

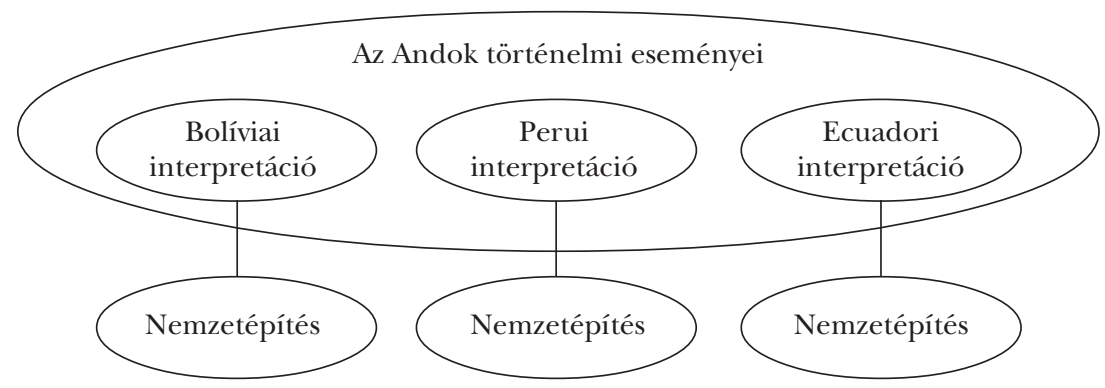

Ez a parciális történelmi tudatépítés talán kedvez a nemzet tagjainak vagy a vezetô nemzeti politikai csoportoknak, ám a történelmi és társadalmi hasonlóságok eltitkolása gátolja az andokbeli népesség közötti szolidaritásérzés kifejlôdését. Erre a szolidaritásra az identitásuk megôrzéséért egyre határozottabban kiálló ôshonos népeknek, illetve az egyes országokban megerôsödô mesztic középosztálynak egyaránt szüksége lehet.

Mindezek alapján az Andok jövendóbeli történelemoktatásának két alternatív forgatókönyvét tudom elképzelni:

1. Az elsố forgatókönyv szerint a domináns (kreol) politikai csoportok képesek lesznek megốrizni és fenntartani saját hatalmi berendezkedésüket, ami részben a jelenlegi államalakulatok, rész- 
ben pedig a jelenlegi parciális történelemszemlélet és -oktatás tartós fennmaradását eredményezi. A meszticizálódás és urbanizáció folyamatának felerôsödésével a jelenlegi, országon belüli etnikai és szociális szembenállás enyhül, a nemzeti különbségek pedig megerôsödnek: Atahualpa és Huáscar harca bizonytalan idôre tovább folytatódik.

2. A második forgatókönyv szerint még mielốtt az egyes nemzeteken belül végbemenne a meszticizálódásnak nevezett középosztályosodás és asszimilációs folyamat, a leginkább hátrányosan érintett csoportok, az ôshonos népesség vagy a városi „csolo” mesztic csoportok egyfajta pánandokbeli összefogásban keresnek megoldást a kérdéseikre. Egy ilyen jellegú politikai változás (a bevezetésben idézett Anthony Smith gondolatmenetét követve) szükségszerúen maga után hozná az Andok történelmének új, az országhatárokon átívelô összefüggéseket is bemutató interpretációját.

\section{Irodalom}

- Anderson, Benedict: Imagined Communities. London, 1983.

- Bernete, Francisco: Como analizar las representaciones sociales contenidas en los libros de texto de historia. Madrid, 1993.

- Hobsbawm, Eric: The Invention of Tradition. Cambridge, 1983, University Press.

- Hofer Tamás Niedermüller Péter (szerk.): Nemzeti kultúrák antropológiai nézetben. Budapest, 1998.

- Letenyei László: Etnikum és hatalom az Andokban. Replika, 29. évf. (1998) 83-96.

- Smith, Anthony Douglas: National Identity. Nevada, 1994, University of Nevada Press.

- Weber, Eugen: Paisants de la France. La modernisation de la France rural, 18701914. Paris, 1975, Gallemard. 


\section{Iskolai történelemkönyvek}

Borth, Carlos: La cuestión nacional. La Paz, 1986.

Castillo Morales, Juan: Historia del Perú en el proceso americano y mundial. Lima, 1993, Editorial Bruño.

Chirinos Montalbeti, Rocio Palacios McBride, Maria: Historia del Perú. Lima, 1997, Editorial Tercer Milenio S.A.

Diaz Suarez, Plácido Narrea Delgado, Manuel Benavidez Estrada, Juan: Historia del Perú en el proceso americano y mundial. Lima, 1996, Editorial Escuela Nueva.

Guevara Espinoza, Antonio: Historia del Perú en el proceso americano y mundial. Lima, 1996, Editorial Guevara Espinoza.

Macera, Pablo: Historia del Perú. Lima, 1993, Editorial Bruño.

Pons Muzzo, Gustavo: Compendio de Historia del Perú. Lima, 1995, Editorial Bruño. 1. kiadás: 1983, Editorial Librería distribudora Bazar San Miguel Ltda.

Pareja Diezcansejo, Alfredo: Breve historia del Ecuador. Quito, 1991, Editorial Ecuador FBT. Cía Ltda.

Villanueva Sotomayor, Julio: Historia del Perú y Geografía. Lima, 1997, Editorial Bruño. 